Florida International University FIU Digital Commons

$3-27-2017$

\title{
History, Material Culture, and the Search for the Mythic American Dream in Angie Cruz's Let it Rain Coffee
}

Michelle Almonte

Florida International University, michellemybellalmonte@gmail.com

DOI: $10.25148 /$ etd.FIDC001800

Follow this and additional works at: https:// digitalcommons.fiu.edu/etd

Part of the Latin American History Commons, Race, Ethnicity and Post-Colonial Studies Commons, and the United States History Commons

\section{Recommended Citation}

Almonte, Michelle, "History, Material Culture, and the Search for the Mythic American Dream in Angie Cruz's Let it Rain Coffee" (2017). FIU Electronic Theses and Dissertations. 3175.

https://digitalcommons.fiu.edu/etd/3175 


\title{
FLORIDA INTERNATIONAL UNIVERSITY \\ Miami, Florida
}

\section{HISTORY, MATERIAL CULTURE, AND THE SEARCH FOR THE MYTHIC AMERICAN DREAM IN ANGIE CRUZ'S LET IT RAIN COFFEE}

\author{
A thesis submitted in partial fulfillment of \\ the requirements for the degree of \\ MASTER OF ARTS \\ in \\ ENGLISH \\ by \\ Michelle Almonte
}


To: Dean Michael R. Heithaus

College of Arts, Sciences, and Education

This thesis, written by Michelle Almonte, and entitled History, Material Culture, and the Search for the Mythic American Dream in Angie Cruz's Let it Rain Coffee, having been approved in respect to style and intellectual content, is referred to you for judgment.

We have read this thesis and recommend that it be approved.

Ana Luszczynska

(and

(n)

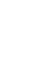

\author{
Heather Russell
}

Nandini Dhar, Major Professor

Date of Defense: March 27, 2017

The thesis of Michelle Almonte is approved.

Dean Micheal R. Heithaus

College of Arts, Sciences, and Education

Dean Andrés G. Gil

Vice President for Research and Economic Development

And Dean of the University Graduate School

Florida International University, 2017 


\section{DEDICATION}

To my parents.

Thank you for believing in me at times when I did not.

Thank you for your unconditional love.

Thank you for showing me the light. 


\section{ACKNOWLEDGMENTS}

There are several friends, family, and strangers whom inspired and fueled me with the drive to write this thesis. To you, I am greatly thankful and indebted.

I first wish to thank the members of my committee, Dr. Ana Luszczynska and Dr. Heather Russell, for their support, guidance, and patience. Finally, I would like to thank my thesis director, Dr. Nandini Dhar. From the very beginning, she had patience and faith in this thesis. Her reassuring guidance and words helped guide me through the process.

To my friends and loved ones. Thank you for your prayers, your words of encouragement, strength, and wisdom. It takes a village to write a thesis, and I could not have done this alone. 
ABSTRACT OF THE THESIS

HISTORY, MATERIAL CULTURE, AND THE SEARCH FOR THE

MYTHIC AMERICAN DREAM

IN ANGIE CRUZ'S LET IT RAIN COFFEE

by

Michelle Almonte

Florida International University, 2017

Miami, Florida

Professor Nandini Dhar, Major Professor

This thesis examines the connection between Dominican history, the influence of American material culture, and the mythic American Dream as catalysts for migration. The two U.S. occupations and American propaganda through media had a great effect on the deceptive perception of an American life as an effortless method for attaining wealth. Let it Rain Coffee by Angie Cruz, will focus on the character, Esperanza Colon, and her obsession with the lavish lifestyle she views on the television show, Dallas. Material objects, as argued by Daniel Miller in his book, Stuff, work in subtle yet significant ways and determine our function, identification, and experience in society. If the ideal purpose of material culture is to presuppose our roles as individuals, one can conclude that the novel showcases the issues of a subordinate class struggling to attain the material goods that represent economic wealth while maintaining a sense of self-identification and selfagency. 


\section{TABLE OF CONTENTS}

CHAPTER

PAGE

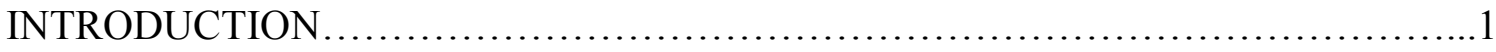

CHAPTER I: MATERIAL CULTURE, MEDIA \& SELF-IDENTITY: THE PATH TO ATTAINING THE AMERICAN DREAM IN ANGIE CRUZ'S LET IT RAIN

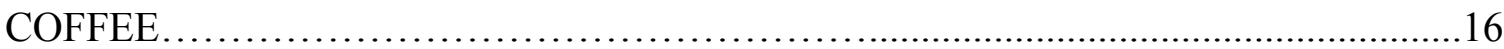

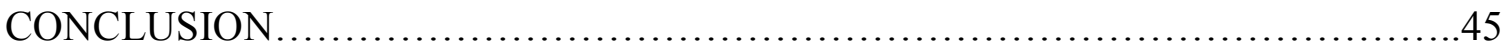

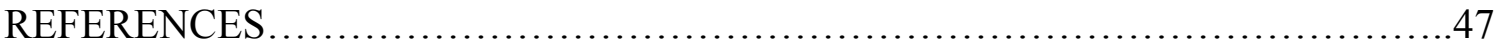




\section{INTRODUCTION}

"Indeed stuff achieves its mastery of us precisely because we constantly fail to notice what it does... They guide us towards the appropriate way to behave and remain unchallenged since we have no idea that we are being so directed. They are particularly effective during the early phases of socialization, where they stand as our teachers, mentors and gurus, leading us to become examples of a specific society, class or gender more effectively than any explicit pedagogic exhortations" (Miller 155).

Let it Rain Coffee by Angie Cruz encapsulates the story of the Colons, a Dominican family who face political and economic uncertainty in the Dominican Republic and then migrate to New York City in search of a better life, a stable government system, and a promising economy. Esperanza Colon is the first of the family to arrive to New York and her migration is fueled by her obsession with the soap-opera, Dallas $^{1}$. Consequently, Esperanza abandons her husband, Santo, and only son, Bobby, to trek to New York City with hopes of eventually moving to Texas and achieving the mythic American Dream of wealth, comfort, material excess, and financial security.

However, Esperanza's migration to New York does not result in economic success. She and Santo work endless hours to provide for their family. Esperanza's true reality while living in Washington Heights, is starkly opposite to Dallas: she works endless hours as a caregiver and comes home to a small two-bedroom apartment and a dysfunctional family. Unfortunately, Santo is murdered while working the night-shift as a taxi driver. Esperanza is left to take care of her two children, Bobby and Dallas, and of her father-in law, Don Chan. As the main provider for the family, Esperanza continues dreaming about living in Texas. Her viewing of Dallas episodes becomes obsessive. The popular and globally viewed soap-opera, portrays the wealthy Ewing family that owns an

\footnotetext{
${ }^{1}$ Dallas lasted 14 seasons from April 2, 1978, to May 3, 1991.
} 
oil company and additionally depicts fictional realities of American success.

Additionally, her paternal family stems from a lineage of supporters for the dictator Trujillo. As patronage for their support, Esperanza's father was rewarded with elite status and comfortable living accommodations in the modern capital city, Santo Domingo. Therefore, the more Esperanza views the show, the greater she is reminiscent of her life in Santo Domingo. More significantly, she desires the lifestyle on Dallas and continues purchasing material goods and accrues debt. Additionally, she does not gain the idyllic American life she desperately wants herself. Hence, Esperanza's obsession becomes representative of her steadfast belief that she can achieve lavish material wealth.

Esperanza's character is emblematic of the misunderstanding of economic success as being solely achieved through white-American culture and through material possessions; hence, Esperanza represents a Dominican emigrant addicted to the mythic American Dream who does not recognize the true reality of American life. In other words, Esperanza believes that America, the land of opportunity, will grant her instant wealth upon arrival to the country, more specifically Dallas, Texas. She perceives economic abundance as easily attainable by anyone who arrives to the United States. Moreover, her interactions with material objects exemplify the effects of the mythic dream because, through Dallas, Esperanza creates an unrealistic and exaggerated version of the American Dream.

Due to the impact of media, the majority of Dominican and Dominican-American characters in Let it Rain Coffee, do not perceive any other form of monetary success but the one portrayed on American television. Within the novel, Esperanza is constantly exposed to the idea of the American Dream as the best method of happiness and wealth. 
In, “The Smell of an Impossible Dream," Valovirta et al discuss the impact as so great that Dominicans took extreme measures and, "The magnitude of this influence is made clear by the fact that about 10 percent of the population of the Dominican Republic migrated to the United States from the mid-1960s to 1990" (160-1). The problem arises when characters, like Esperanza, are unable to achieve such luxury because they are simply not economically capable. In the D.R., class inequalities and a coinciding economic system do not allow much room for prosperity. Additionally, in the U.S., less than $10 \%$ actually attain the type of lifestyle Esperanza desires; the American Dream is inaccessible to the majority of Americans. The American Dream thus becomes a mythical and ideological concept because it becomes harder to attain. The ideal American lifestyle, filled with wealth and economic stability, is unfeasible for emigrants like Esperanza because the types of jobs available to them were manufacturing jobs that offered minimum wage salaries. In Esperanza's case, she lacks educational qualifications and skills to get more well-paying jobs. While in the Dominican Republic, she continues attempting to gain the mythic American Dream. The television show, Dallas, continuously fuels Esperanza's desire and becomes the catalyst for her attempt at attaining a life of wealth and she migrates to New York. In, "Shared History of the United States and the Dominican Republic in Angie Cruz's Let it Rain Coffee", Rasha Al Shalabi argues that, "Esperanza continues to be an easy prey for the US media which encourage belief in upward social mobility within the North-American society" (5). However, such desires are so deeply ingrained in her that she does not see their constructed nature; just in the same way, Esperanza does not initially comprehend the functions of the American economic system. She continues purchasing material goods because she thinks it is the 
key to attaining the success and happiness she desires.

In Let it Rain Coffee, Cruz exemplifies how political context and history impacts the lives of many Dominicans, like Esperanza. The effects of imperialistic society are represented through the experiences and struggles of a character living in a lower economic class. Through Dallas, Esperanza creates a fictional world. Her aspirations coincide with the characters from the television show whose lives are depicted as affluent and representative of the ideal white-American family; a life of material lavishness. A correlation between Esperanza's consciousness and economic history in the Dominican Republic exists because her intellectuality and subjectivity is determined by the ideologies created and implemented by a powerful nation, the United States. Esperanza's perception is also affected by the ideologies of white favoritism enforced by the Dominican leaders and, more significantly, the Dominican dictator, Trujillo. Furthermore, the history of the Dominican Republic presents better understanding of cultural and racial divide within the country.

Since the Dominican Republic gained independence from Spanish rule, in 1844, the country took many measures to adhere with the United States' cultural imperialism and superiority. Throughout Dominican history, elite and powerful leaders have imposed their perception of the white race as the dominant race. As a result, a racial divide was influenced by efforts to strengthen the economy and by efforts to appease U.S. policies (Atkins and Wilson 57). This perception was initiated by the need to strengthen the economy and by the need to form political alliances with the United States. Dominican political leaders and important figure heads continued maintaining an attitude of white superiority in efforts for political alliance with the U.S. Consequently, the D.R. attempted 
altering their economic, racial, and religious spheres in hopes of improving their government and economic system. The U.S. assisted in providing American cultural and political influences when it occupied the Dominican Republic.

Because of political issues on the island causing a war, the first U.S. occupation provided stability for the Dominican Republic. However, the United States eventually withdrew in 1924. This departure left the Dominican Republic in a much improved governmental standing than the eight years prior to the occupation. Unfortunately, the political development and economic achievements established during the occupancy did not last. The country fell back into instability and chaos. Soon, the six-year democracy set in place by the United States was replaced by a long-term dictatorship.

Rafael Trujillo rose to power during the U.S. occupancy while he served as lieutenant and earned a reputation for intelligence and efficiency. For three decades, the Dominican Republic remained under Trujillo's rein. Any Dominican citizen who dared question Trujillo's authority was met with violence, torture and execution. During this time, the dictator practiced white supremacism and glorified Spanish ancestry as the only racial genealogy of Dominicans. He held the belief that a white racial image of the Dominican Republic would gain the support of the U.S. ${ }^{2}$ Consequently, the Trujillo era resurfaced past racial tension between the Dominican Republic and Haiti. The Haitian tragedy in 1937 marked the extent of Trujillo's racial favoritism when he ordered military forces to attack and kill a massive amount of Haitian and black Dominican peasants residing near the border of the two countries. Atkins and Wilson discuss Trujillo's policy

\footnotetext{
2 "Trujillo's dictatorial control helped perpetuate the mythical cultural and racial image of the Dominican Republic, one he believed was appreciated by and consistent with the views of U.S. civilian and military decision-makers in a racist U.S. society with legal racial segregation" (Atkins and Wilson 78).
} 
and personal view of "Dominicanization," an, “. . . effort to eliminate the perception of 'blackness' from Dominican society, reinforced by the fear of 'Ethiopianization' of Dominican Republic by Haitians through racial and cultural mixing. It specifically involved removing Haitians by any means" (72-3). By perpetuating a "white" racial genealogy, Trujillo controlled the perception of all Dominicans and imposed the belief that black ancestry is unfavorable for progress, sophistication, and success. He additionally controlled all media outlets such as television channels and news print by censuring any information that would hurt his image.

During the 1930s, Trujillo controlled all forms of media such as television and newsprint. By supervising and establishing his own methods of mass communication, he maintained his regime. From the beginning of Dominican television, the media was skewed to gear audiences toward favoritism for Trujillo and preference for American culture and products. Only two television channels existed, La Voz Dominicana and Rahintel. The latter channel, Rahintel, established in 1959, was aimed at the younger population and emphasized American culture by showcasing mostly U.S. movies and shows. By monitoring all television and newsprint media, Trujillo ensured glorification of his image and glorification of white-American culture. Soon, Trujillo was assassinated in 1961; however, his three-decade reign left a residual influence on the Dominican Republic, and many citizens were not able nor capable of erasing the dictator's impact. The presidents, Juan Bosch and then Joaquin Balaguer, took office during post Trujillo era; their presidencies demonstrate the effects and the damages caused during the dictator's regime. 
Joaquin Balaguer's emphasis of American values and culture was perhaps an indirect result of American material culture. Balaguer served as elected president of the Dominican Republic for three terms, and his greatest influence during his presidencies was the emphasis of North Americanization through material commodities. The phenomenon of American influence in the form of goods and cultural values on Dominicans through radio, television, movies, and the resultant migration of Dominicans to the U.S., is termed as Northamericanization. This cultural influence dates to the 1880 s and some argue that it, was an inevitable result of “... the proximity of the two states and the consequent migration, commerce, and cultural contact and 'penetration' (Atkins and Wilson 156). Coupled with U.S. material cultural impact and hispanidad, Dominican identity made a drastic shift in the late 1960s: "Northamericanization coalesced and increased its pace after the end of the era of Trujillo and the phenomenon 'took off' after 1966" (Atkins and Wilson 157). Dominican identity thus became impacted by American lifestyle. Many Dominicans merged their identity to match the mix of Spanish culture as well as American influence. This merge occurred because on the one hand, a majority of Dominicans developed a sense of inferiority. On the other hand, upper and middle class Dominicans developed a preference for U.S. products and lifestyle. As time went on, Dominicans became more and more impacted by U.S. media. Many Dominicans developed a false sense of the appropriate methods for gaining economic wealth because the country became influenced by American consumer society projected via television, radio, and other American advertising.

U.S. propaganda suggested American life as exceptionally comfortable, easier, luxurious, and economically and politically stable. To Caribbean countries, such as the 
Dominican Republic, with histories of poverty and political turmoil, the portrayal of American wealth was an attractive and persuasive image. As a result, many Dominicans redefined their idea of a better life to signify living in America and attaining the material wealth and the economic stability they saw on television shows and advertisements. The influence of American media was so great that many Dominicans lost sense of their own economic reality and began attempting to attain the life projected on the television by spending the little money they possessed. Their concept of wealth and cultural identity became skewed and many Dominicans failed to recognize the extent of their identity and economic freedom through self-agency, if any, being at stake. Therefore, the impact of material culture plays a crucial role in relation to an individual's self-identity, selfagency, and sense of culture and heritage.

In Stuff, Daniel Miller demonstrates the importance of material objects as, “. . .the best way to understand, convey and appreciate our humanity is through attention to our fundamental materiality" (5). Miller defines various terms and theories important to the field of material culture such as function, the humility of things, and objectification. The term function aims to provide a direct and literal explanation of why individuals own specific objects for specific tasks: "Function tends to remain our default gear in driving towards any explanation of why we have what we have. It is why we label goods from frying pans to swimwear" (Miller 44). Nonetheless, if an object is functional and administers the function it is meant, then the object has relevance and importance. However, function becomes complex when it applies to an individual's unique adaptation to his/her environment. Certain objects, such as a water vessel, can serve different uses and change meaning depending on context and environment. 
Relying upon the expectation for a certain behavior, a specific object can provide a type of function. In other words, a wedding dress would not serve its function if it is not used in the context, or frame, of a marriage-ceremony; however, this same dress can administer the purpose of clothing the body outside the context of the ceremony. Miller presents that, "... much of our behavior is cued by expectations, determined by the frames which constitute the context of action" (49). Additionally, Miller uses the idea of frame to exemplify the correlation between expectation and environment because certain objects create the setting, or foundation, for a desired social behavior. These objects operate as social cues and often work as silent yet powerful reminders of anticipated behavior. The expected action or behavior within an environment, framed activity, has the ability of simultaneously constraining and enabling the individual. If we are to view an object that appropriately forms the setting for an activity, the frame remains unnoticed and unchallenged because it has been deemed as socially acceptable. However, when the use of an inappropriate frame occurs, such as an object used for an activity not usually associated with the act, we become aware of the misuse of the frame. For example, if one were to enter a room with a podium in the middle of it, one quickly assumes that the room serves the purpose of a lecture-room. If a speaker were to enter the room and merely stand behind the podium and conduct a one-on-one conversation with another individual, the podium no longer furnishes its function, and the desired activity of a speech within a lecture-room no longer holds relevance. If we are to only follow the social cue that the podium is a device for lecturing, then the object constrains the individual because, "The less we are aware of [objects], the more powerfully they can determine our expectations, by setting the scene and ensuring appropriate behavior, 
without being open to challenge" (Miller 50). It is through this realization that the significance of material culture theory arises; by discussing the things that constitute a particular activity, yet remain unnoticed.

Things can seem so trivial that they do not hold significance; however, Miller refutes this idea by reminding us, “. . that when something is sufficiently evident, it can reach a point at which we are blinded to its presence, rather than reminded of its presence" (Miller 51). An object achieves definition when we encounter the opposite of what it is not and recognize what it is; for example, a podium is not an object intended for private conversation; rather, it is an object used for lectures or public speeches. Miller explains that, "Both the objects, and the words we use for them, achieve definition by contrast with what they are not, as much for what they are" (51). Additionally, intellectual activity, or rather framed activity, provides the foundation for objects to serve as meaningful and intentional tools; a table is more than a flat surface with four legs underneath, and a wedding dress is more than a white garment. The activities of sitting at a table and having a meal or of wearing a wedding gown for matrimonial union thus become complex. However, not every society creates the same objects for the same activities. Evidently our understanding of specific cultures comes from constant practice within our everyday activities and interactions.

Miller discusses the importance of practice by emphasizing the humility of things and the system of things within a societal structure. As previously stated, objects remain quiet, yet constant, reminders of expected behavior. Consequently, from the moment we come into existence, we are surrounded by objects awaiting our utilization, interaction, and exchange: "Before we can make things, we are ourselves grown up and matured in 
the light of things that come down to us from the previous generations" (Miller 53). The way an individual relates to objects or specific objects and the reason for this person's fixation on a certain thing as the center of his/her attention is directly related to his/her role in a societal system. This fixation on material things occurs at a subconscious level in which we habitually and innately interact and use objects, within a cultural environment, without much thought. The cultural environment represents a social system of material objects that formulate the foundation for a person's identity. In other words, all individuals interact within a societal structure contrived of material objects which assist in intrinsically forming our identities. As Miller states, it is, "Things, not . . . individual things, but the whole system of things, with their internal order, make us the people we are" (53). Therefore, material objects and the corresponding behaviors and social interactions are crucial to the creation of an individual's sense of self or selfagency. Furthermore, objectification plays a significant role in the subjective experience and a person's relationship with the external world.

Per Miller, objectification, in accordance with material culture theory, is the process of an individual stepping outside his/her internal consciousness and fixating on the external, material reality. Through this fixation, the individual transcends to a new level of sophistication. Miller further explains, objectification is, "the way we enhance our capacity as human beings" (59). The purpose of fixating on and making objects is to extend ourselves and our human experience. Through the creation of objects and the labor that goes into making them, we reach higher levels of sophistication and modernization. Miller explains that, "Our social evolution consists not of advances in consciousness per se but in our increasing capacity to create an artifactual world ... first 
stone and pot, then agricultural systems, urban life, and finally the industrial revolution, which represent[s] a vast acceleration in our capacity to create stuff' (Miller 58).

Additionally, labor is additionally important because it builds complexity and knowledge and, "The object of labour is therefore the objectification of the species-life of man: for man reproduces himself not only intellectually, in his consciousness, but actively and actually and he can contemplate himself in the world he has created" (Miller 59). And so, the individual creates something outside him/herself, and the object then becomes an extension of the human experience that intellectually matures the person; hence, a more profound human experience within the subject's society and culture is created. Consequently, external focus on something other than oneself equates to objectification. However, there is a negative effect to objectification when the 'thing' itself becomes autonomous and oppressive. Every time we enhance our capacity as human beings, ". . . by the very same process we also create a contradiction, a possibility of oppressing ourselves if the thing we made then develops its own autonomous interests" (Miller 59). Miller uses the car as an example of an autonomous and oppressive object because although it provides a means of transportation, the car also creates pollution, accidents, and the destruction of natural landscapes for motorways. However, great benefits also stem from the creation of objects such as a vehicle for faster transportation. Once an object, such as a car, is created, the existent humanity is forever transfigured. Overall, material culture presents a paradox because objects can expand and simultaneously constrain the human experience. Through objectification and the contrasting possibility of autonomy, or loss of control, great benefits stem from the creation of objects because they present silent sign-posts for expected behaviors across 
different cultures and extend our intellectual horizons. However, the drawbacks of objectification in relation to Let it Rain Coffee are reflected in Esperanza because of the constraint, such as debt, caused by her obsession with material objects.

In many ways, Let it Rain Coffee presents the racial, political, and economic struggles of many Dominicans and Dominican-Americans. The novel additionally demonstrates how inhabitants of Caribbean countries and first generation emigrants in the U.S. respond to the American Dream by attempting to helplessly achieve material wealth and economic stability by any means necessary. And so, American media plays a significant role in determining the perception of material consumption to other nations like the Dominican Republic. Certain types of institutional ideologies and perceived knowledge affect a person's everyday experience. An individual like Esperanza perceives her unique societal experience in accordance to social function, the humility of things, and objectification in relation to the objects available for her use and possession. Moreover, Esperanza perceives reality through her specific connection with material objects and possession; hence, objects seep into Esperanza's life in subtle unseen ways. In Stuff, Miller discusses material objects, their function in society, and the relation with material culture: "They work by being invisible and unremarked upon, a state they usually achieve by being familiar and taken for granted. . much of what makes us what we are exists, not through our consciousness or body, but as an exterior environment that habituates and prompts us" (50-1). Esperanza fixates on things outside of herself and this fixation has positive and negative repercussions. Dallas and things both expand and constrain Esperanza. Instead of making objects, Esperanza purchases them; through purchasing objects, she extends her human experience. 
Additionally, Esperanza's ideas, concepts, and consciousness are all connected to the material things she has access to or needs in her society. These ideas and perceptions are the result of social realities or dominant ways of perceiving the world. Thus, function becomes an important factor in determining how men/women, like Esperanza, fixate on certain objects or use them to live out their roles in class-society. This fixation is a form of objectification and can enhance the human experience or restrain the individual. The negative effects of objectification prevent the individual from attaining greater, or true, knowledge of self-identification because the object becomes autonomous. Through the television show, Dallas, Esperanza is consumed by the effects of a capitalist and consumer culture. Objects such as figurines, hair, clothing, and even her husband, become tools for Esperanza to improve her economic situation and emulate the lavish lifestyle she views on Dallas. Therefore, her interactions with objects and her reaction to the show demonstrate the desire for the mythic American Dream due to the absence of certain material possessions. Moreover, Esperanza's decision to migrate results from gradual buildup of cultural inferiority and frustration; hence, American influence spurs her hasty departure to the United States. Upon arriving to the United States, she assumes immediate acquisition of the American Dream by purchasing many objects but instead acquires debt. As a result, the show distorts Esperanza's sense of identity and self-agency because she believes she must possess the material objects and biological characteristics of the prominent characters on Dallas. Esperanza loses sense of self-agency within a capitalistic society when she accrues debt. After accumulating too many material objects, the immense sum of money that she owes pushes Esperanza to gain control of her spending habits and of her credit-debt. Eventually, she finds independence and self- 
agency from the influence of American consumer culture in the end of the novel when she seeks assistance from a credit union bank teller. Finally, she is impelled to rid herself of things that are now far less valuable to her when she goes to the Dominican Republic and gives away most of her material possessions. 
CHAPTER I: MATERIAL CULTURE, MEDIA \& SELF-IDENTITY: THE PATH TO ATTAINING THE AMERICAN DREAM IN ANGIE CRUZ'S LET IT RAIN COFFEE In Let it Rain Coffee, Esperanza Colon initially lives in the Dominican Republic but becomes obsessed with the material excess depicted in the television show, Dallas. Esperanza's obsession with the show symbolizes limited access to material wealth. She cannot attain the material commodities she views on television because she lives in a dilapidated house in Los Llanos, a poor country town in the D.R. The few material goods she does own are rusted, badly manufactured, and are no comparison to the lavish goods she sees on Dallas. On a grander scale, her entire country has been deprived of material commodities that would make their lives more comfortable. However, Esperanza is different from the people of Los Llanos because she was raised in the modern capital city, Santo Domingo, and experienced a higher her class position which fuels her dreams. As we recall, her family comes from a lineage of Trujillo supporters who were monetarily rewarded for their support and benefitted from comfortable housing and privileged lifestyles.

As previously discussed, from the beginning of the Dominican Republic's independence, Dominicans have experienced economic imbalance and racial inequality. Many still struggle to fill basic needs for survival such as drinking-water, food, and shelter. Small populations of Dominicans are fortunate to own homes made from concrete, have electricity, have running water, and own televisions. Through characters such as Esperanza, Cruz illustrates the journey of many immigrants aiming for a better life in the United States. More significantly, Esperanza's migration is a representation of the emigrant's journey and the desire to achieve the mythic American Dream. As 
previously mentioned, the influence of American propaganda convinced less affluent countries in the Caribbean into believing that living in America and attaining material wealth and economic stability is the ultimate way to live. Therefore, Esperanza desires what she sees on Dallas and desperately seeks that lifestyle in the United States.

In many ways, objects such as clothing, home goods, and hair operate as propelling forces motivating Esperanza to act. In Esperanza's case, her poverty does not allow the opportunity for overcoming the distance between herself and the objects she desires. The epitome of her desire for objects surfaces when she lives in Los Llanos and decides to migrate to New York City; however, she fails to achieve the economic status she wants or even economic stability because she remains obsessed with buying her way to becoming like an Ewing from the show Dallas. Nonetheless, Esperanza's objects serve the function of emulating the objects from the show.

Esperanza constantly cleans and shifts the function of her objects because she desperately wants her home-goods to appear new and expensive, like the objects she sees on Dallas. We see this when Esperanza attempts to shine the objects: "But no matter how much Esperanza polished her utensils, mirrors, the glass figurines on the shelves, they never shone for long. The dust was persistent. The condensation, salt, and heat made a coat of dirt on everything" (Cruz 14). She cleanses the objects she owns to make them resemble the objects on Dallas. More significantly, Esperanza cleans her things because they provide more than their ordinary function. As previously mentioned, the function of an object can shift depending on environment and context. The expectation, or social cue, of an object can set the standard, or frame, for the established or expected behavior from a person. In relation to Esperanza, she does not own objects of high value, hence the 
social cue learned from Dallas inflicts a desire for similar objects from the television show. By constantly cleaning, Esperanza alters the function of her utensils, glass figurines, and mirrors; these objects no longer serve the purpose of tools for eating or viewing one's reflection. In other words, Esperanza's social experience is determined by the material culture she lives in because reality is perceived through an individual's specific connection with material production; by cleaning her objects, Esperanza's makes a material connection with her reality through Dallas. However, Esperanza perceives Los Llanos as a place of implacable dust and decay.

In contrast to the abundance and productivity she views on Dallas, her possessions are worn out and dirty and will remain this way because of dust coming in from the outside. More significantly, the persistent dust depicts poverty because of residue rising from the dirt roads that differ greatly from the modern and paved roads of Santo Domingo, Esperanza's former paternal home. When she cleans her objects, Esperanza refuses to allow her things to remain dirty and she follows the tradition of privileged life she experienced while growing up in Santo Domingo. Before marrying Santo, her paternal family lived in the capital city and supported the Trujillo dictatorship: "Esperanza was from the de los Santos clan. Many of the men in her family worked for Trujillo, and throughout the years supported his predecessor, Balaguer" (Cruz 18). The people of Los Llanos did not have gravel roads like Santo Domingo. As a result, Esperanza's dream of a prosperous future where she owns bright and expensive items is faded out, and threatened, by the dust that settles on all her home possessions and belongings; in such a way that the dust foreshadows her failed attempts for monetary wealth. Additionally, the repetitive act of cleaning her objects symbolizes the Dominican 
reaction to American influence and the attempt to gain more personal worth by emulating anything white and American. And so, Esperanza's desire and sense of function for things exists because of the social experience enforced through American television.

Through television, American ideology greatly influenced and changed the views of poor populations, like Esperanza. Although she comes from an affluent family background, Esperanza marries Santo and now lives in poverty in Los Llanos. Esperanza desires material wealth and this is apparent when she begins, “... using words like buying, selling, profit, inheritance" (Cruz 17). The D.R. experienced U.S. influence in the form of media and imported goods during Trujillo's regime and through Balaguer's first presidency. Although poor populations were restricted from obtaining imported material goods, the influence of American culture through media made a strong impact. In the novel, Esperanza readily buys into and consumes the messages of comfort and luxury. Here Dominicans, like Esperanza, represent the effects of ideology because they focus their attention on fantasy-like narratives of wealth. Esperanza perceives the wealth portrayed in American shows and commercials as the normal economic status for all U.S. citizens. Thus, she desperately seeks attaining or mimicking this same form of prosperity. Additionally, Esperanza takes it a step further because she learns lessons from Dallas. Cultural theorists like Stuart Hall opine that this type of ideology represents a dominant group which owns the means of production and control the means of producing: "through the dominant group's ownership of media outlets, dominant classes subject the masses to ideologies which form the social relations and make them appear natural" (347-8). By Americanizing the perspectives of Dominicans, like Esperanza, America becomes the dominant nation influencing and subjecting other classes to their views and forms of 
thinking through media. In the novel, television played a major role in "Americanizing" the minds of many poor Dominicans through constant reminders of things they were lacking such as comfort and ease in the form of material goods. Dallas and other forms of American media exposes Esperanza to certain forms of thought and behavior used in consumer culture. Terms like buying, selling, profit, and inheritance are foreign to Esperanza. Her current economic reality does not allow for her to utilize nor take part in the type of consumer behavior or situation in which selling, gaining profit, or inheritance would be needed because Esperanza is now poor. Nonetheless, the repetitive viewing of television programs, like Dallas, represents an impediment to a stable economy; and so, economic stagnation exists.

While living in Los Llanos, Esperanza experiences hunger and poverty due lack of economic growth. Her stomach symbolizes an economic void because of lack of opportunities for monetary advancement and prosperity: "And when her stomach was empty, unlike her neighbors back home who spent afternoons in their patios waiting for the electricity to come back on, embellishing stories about absent neighbors, with the air always smelling of sweat, rum, and frankincense, Esperanza had her eye on more glamorous things..." (Cruz 16-17). Esperanza and her neighbors do not have the option of working and gaining more income. In the novel, American material culture represents the class in possession of the lavish goods and economic methods of production; therefore, it provides the structure for fantasy-like narratives of economic wealth. However, the people of the Dominican Republic, more specifically the citizens of Los Llanos, represent people that cannot attain commodity goods and perceive this poor economic circumstance as natural. By perceiving their state of poverty as normal, their 
social consciousness is constrained; this is epitomized when Esperanza's neighbors, wait for the electricity to return. They have become so accustomed to their continuous state of poverty, that they do not attempt to agitate nor change their situation. Additionally, the citizens of Los Llanos have also witnessed the detrimental and failed attempts of political groups whom attempted to revolutionize the Dominican government and bring economic equality for the poor. During Juan Bosch's brief presidency of seven months, February 27 th, 1963 until September 25th, 1963, many of the poor population, such as urban workers and small farmers, supported Bosch for his efforts to bring balance to the economy. However, Bosch's attempts were unsuccessful and resulted in a civil war, from April 24, 1965, until September 3, 1965 (Atkins and Wilson 134). And so, Esperanza and her neighbors turn to television to escape their current economic void. However, Esperanza takes it a step further than her neighbors because she does originate from the same class position as the rest of the residents in Los Llanos.

Esperanza holds a different mentality than her neighbors in Los Llanos because she used to live in Santo Domingo with her father and benefitted from upper-class living and accommodations. This is apparent when she is naturally drawn to glamour and shiny things: “. . Esperanza was more like a moth. Attracted to the lightbulb, plain and pesty" (Cruz 13). Here the allusion to a moth symbolizes Esperanza's obvious yet unrelenting impulse to gear towards hopes of lavish goods and monetary prosperity. This impulse results in Esperanza filling the void in her stomach with hope for an American lifestyle of comfort and wealth; it also sets her apart from the other inhabitants of Los Llanos. Her desire for the objects is obvious; however, her reason for it, Dallas and the mythic American Dream, remain ambiguous. As a result, the constant reminders portrayed in 
American television shows and propaganda subtly encourage a natural and continual desire for individuals, like Esperanza, to look to the United States for any chance to acquire material wealth. On the other hand, Esperanza's chances of acquiring economic prosperity are slim because of an imbalance in the Dominican economy.

Esperanza's residence in Los Llanos during Joaquin Balaguer's second presidential return to office epitomizes an inequality in material wealth because small percentages of wealthy Dominicans enjoyed material prosperity and luxuries. However, Balaguer's policies and programs to modernize the country only served to benefit the elite class. Plans to reduce poverty in the Dominican Republic fluctuated from hopes of progress for all economic classes to prosperity only offered to affluent Dominicans. Consequently, the minimal amounts of commoditized objects and opportunities for economic advancement available to the poor class, in towns like Los Llanos, represent hopes of modernization and wealth as bleak. There is no manufacturing, exchange, or access to commoditized goods that create economic growth and evidently the lower class cannot offer labor for profit. More significantly, the lower class barely have the means to find food; thus, the people of Los Llanos are not able to participate as producers or consumers in the exchange of material goods. If most of the economic opportunities are being offered to the rich, there are no jobs for the poor. On the other hand, Dallas demonstrates a template for the objects that Esperanza desires; even if she cannot afford the objects.

The objects Esperanza views on Dallas have become such an integral part of her life, that they determine her expectations and actions; the show provides the setting for the things she wants. Comparing her ceilings and windows to the ones on Dallas 
represents the unconscious influence of objects. This is most apparent when Esperanza complains to Santo about, “... the low ceilings she had to live under and the lopsided holes in the walls they called windows" (Cruz 13). Each viewing of the show is not about Dallas but about the lavish things she sees on Dallas. It is the material things Esperanza recognizes and desires on the show that form the setting of not just the show, but also her life; they present a setting that Esperanza attempts to re-create because her present class identity is one of poverty and bleakness. She aspires toward the class identity of wealth projected on Dallas because she believes she can recreate it through material objects. As previously stated, Esperanza is unlike her neighbors, who sit on the patio and wait for electricity. She plans for a better, wealthier, future by attempting to recreate the fictional reality portrayed on Dallas. Desiring a life like the one from the television show greatly differs from the life Esperanza had in Santo Domingo and in Los Llanos; she desires to attain a much higher class status than the ones she previously had and currently attains. Furthermore, by taking this type of action through objects, her subjective experience differs from the rest of the citizens in Los Llanos. In other words, Esperanza is unique from the others around her because she has hope and specific expectations of prosperity for her future. The subconscious effect that the objects are having on Esperanza influence her to the extent that she wants her material surroundings, her home, to match the material setting she views on Dallas. The ceilings and windows on the show create the frame for Esperanza's living space, her home in Los Llanos. Although the structural components in her current home provide the common function of providing shelter, they do not serve the desired function Esperanza expects for a house because she wants tall ceilings and grand windows. 
Thus, Esperanza's range of possibilities gains expansion because Dallas presents a template for economic advancement. Without Dallas, Esperanza would not have a point of comparison to realize and dream of a different reality as a solution for her poverty. This influence occurs at a subconscious level because Esperanza is not aware of the gravity of the show's material and cultural influence on her thoughts and actions. Through the objects Esperanza views, the show serves as a reminder of leaving Los Llanos and the possibility of monetary prosperity in America. Consequently, the impact of objects on Dallas cause Esperanza to exercise active passivity by becoming an active spectator; the type of spectator who takes some form of action when watching a show. Therefore, Dallas is no relaxing matter; the show constantly reminds Esperanza of the sacrifices she will make to improve her livelihood and acquire self-agency. She will migrate in exchange for the material life she desires.

By viewing television, Esperanza performs active passivity and develops into an active spectator because of the influence of false ideologies within the show. Although obsessive viewing of Dallas may cause viewers to become inactive, Esperanza takes passive action: "Esperanza watched la Loca's TV as if she had been touched by gospel. In desperation, behind Santo's back, Esperanza saved up penny by penny for her trip to Dallas" (Cruz 16-17). Esperanza's repetitive viewing of Dallas causes her to want a different life, a different future, and more self-agency. Rather than waiting around like her neighbors, Esperanza saves small amounts of cash and migrates. In, "Watching Dallas: Soap Opera And The Melodramatic Imagination” Ien and Millen discuss what the average viewer seeks from watching a television show: "For the great majority of the population, television viewing is associated with entertainment: it means 
relaxation, resting after the day's work" (46). For Esperanza, the show exhibits the type of society she wishes to participate in because of the realities portrayed within. Although the identity of being an active spectator is based on her ideological misconceptions about America as a land of prosperity. Esperanza recognizes the extent of her poverty and expands her social experience by planning migration to the United States and planning to acquire an immense amount of material objects like the ones on the television show and advertisements. Ang further explains that usually a viewing of the show provides, "Pleasure in Dallas [that] is therefore associated with the pleasure of the freedoms of entertainment, in which people feel released from the prohibitions and demands of society" (21-2). Esperanza views many things she wants but cannot attain because they are not easily accessible. Her continuation of viewing Dallas and planning her trip to the United States exhibit that she is not freed from the demands of society and does not have self-agency. Instead, the show reminds her of the things she wants to acquire to feel like she is closer to depiction of American life televised on Dallas. Nonetheless, while the television show causes Esperanza to be an active spectator, Miraluz does not desire the mythic American Dream and stays in the Dominican Republic.

Similar to Esperanza, Miraluz does not originate from Los Llanos; she initially moves there to take care of her sick grandmother. Although Miraluz's origins remain a mystery, her devotion to social activism in the Dominican Republic become the focal point of her characteristics in the novel. Miraluz lives in Los Llanos and does not think in terms of material objects like Esperanza. Instead, Miraluz becomes involved in social activism when Esperanza's father-in-law, Don Chan, formed the Invisible Ones, an activist group dedicated to cooperative economics, social equality, and change for the 
poor population in the Dominican Republic. As a young woman, Miraluz begins attending the meetings for the activist group. Her attendance to these meetings is uninvited because the group is comprised strictly of men; yet Miraluz continues attending in hopes of assisting in the creation of a better and more stable political climate. Long after the Invisible Ones dissimilates, Miraluz's social and political devotion does not cease. She stays in the D.R. and soon creates her own activist group, El Secreto de la Victoria, by assisting the other women in her community to become economically independent.

Miraluz represents the number of Dominicans who refused to migrate because they hoped and planned for the betterment of the economic and political circumstance in their country. They also did not view American influence as beneficial for their country. This is most apparent after the second U.S. occupation when many activists gave up the fight for a revolution. The U.S. army took over, and soon after Balaguer became president. They did not view the assistance from the United States as a benefit because they desired independent liberation. Some Dominicans fought against foreign aid not just because they wanted independence, they also desired own sense of Dominican identity. Nonetheless, many disillusioned Dominicans accepted defeat ceased all attempts for a change.

Yet, Miraluz epitomizes those Dominicans who continued believing and envisioning a better future for themselves and their families within their own country: "Even after 1965, when many of the Invisible Ones fled the country or became too disillusioned to fight for anything but themselves, Miraluz stood in front of the American tanks that rolled through her streets, refusing to believe that it could be that easy to be 
defeated by them" (Cruz 221). This passage signifies Miraluz's desire to take political action in attempts to improve the conditions in her community and her country. Instead of fleeing to the United States, Miraluz creates an all-woman revolutionary group, El Secreto de la Victoria, where they produce women's undergarments as a method to become economically independent.

Miraluz and the women of her community work as seamstress in a factory for Victoria's Secret lingerie in La Zona Franca. La Zona Franca was the major free-trading post in Santo Domingo, bringing in most of the economic gain from international trading. As a result, Miraluz creates El Secreto de la Victoria as a response to the Free Zones and it represents a critique of capitalism; it additionally represents a subversive act against idea of capitalism. Miraluz's aggravation with the economic status and the conditions that she must work in, initiate the formation of, El Secreto de la Victoria because she frustrated with the lack economic advancement and the poor working conditions. An inside look into the manufacturing of commodity objects that are traded internationally is depicted in the factory scene: "[Miraluz] looked at the women in the factory, stuffed like sardines, without elbow room, backs hunched over, one beside another, under artificial light, the machine trilling and churning without ceasing. The overseer yelling, --Rapido, rapido. Women squeezing balls of fabric in between their legs, while they trembled because they were afraid to ask for permission to go again to the bathroom" (Cruz 223). In this depiction of the factory, the conditions of the workers' environment emphasize the effects of material culture and the process and sacrifices made to meet the demands of mass consumer society, more specifically American capitalism. For Miraluz, commodity objects are tools for social, political, and economic independence. Contrary to Esperanza 
who feels the need to move to another society to make any progress, Miraluz determines to remain in the D.R. and act to change her own native society by forming an all-women activist group. However, Esperanza is completely outside of this type of subversive act against capitalism because she attempts to make capitalism a positive benefit for her. Dominicans like Esperanza desired to be more American by any means necessary. Therefore, Esperanza's hair becomes the focus of a tangible and available object for altering and emulating white American identity.

Esperanza alters her hair to look more American and draw closer to the mythic American Dream. Yet her hair resists imposed styling methods, thus revealing behavioral constraint caused by Dallas. Esperanza fights against her natural biological characteristics in hopes of mimicking what she sees on Dallas, which consists of having white Caucasian features: "And the short feathery bangs that looked so great on Pamela didn't survive the humidity of D.R. No matter how much lye Esperanza combed through her hair, it curled and crimped and fanned out like an old broom" (Cruz 14). Here we see Esperanza's hair recoiling to its natural state, regardless of the amount of product she applies. We return to function and recall the idea that objects are manipulated to provide a desired social behavior. In this case, Esperanza has manipulated her hair to fit the frame created by Dallas because she craves the type of whiteness portrayed on the show. To Esperanza, Americanness means white skin tone and sleek hair. On the other hand, her hair resists the imposed behavioral code because the object, Esperanza's hair, and the act of attempting to make it look "white", are inappropriate.

Dallas provides inappropriate object framing, and Esperanza's hair resists her styling methods. Certainly, Esperanza is trying to adhere to the dominant societal coding 
she views on the television show. According to Ashely Kunsa in, "History, Hair, and Reimagining Racial Categories in JunotDíaz's The Brief Wondrous Life of Oscar Wao", "By making one's hair whiter, a non-white person (typically a woman) can make herself more physically attractive to the dominant culture, and she can indicate her compliance with white social and cultural norms" (220). Esperanza's bangs are not like Pamela Ewing's. Additionally, Esperanza's hair is representative of Hispanic hair, which will never truly resemble Caucasian hair like the protagonists on Dallas. It becomes clear that Esperanza is indeed attempting to fit a mold, in this case, a frame, that simply does not fit. However, this does not prevent Esperanza from believing that whiteness equates to perfection: “. . . she memorized the way Pamela Ewing wore her hair, feathered up and tied in the back in a French twist. She envied Pamela. Why couldn't Esperanza have all the things she wanted? It wasn't fair" (Cruz 31). Here the sense of unfairness represents Esperanza's shame of her own Dominican identity. Hence, Esperanza perceives a happy and generous life must equate to Pamela Ewing's life, one of a white-American woman with a perfect hairstyle. Because of her paternal family history of Trujillo supporters who believed in white-supremacy, she is directly conditioned into thinking that white is indeed the more powerful and elite race and that she belongs to this type of elitism. Consequently, hair becomes representative of Esperanza subverting her own Dominican features in pursuit of a more white-American appearance and identity which she has formulated from watching television.

In the novel, race and ancestral history become a focus of shame and modification when Esperanza alters her hair in attempts of looking wealthier and gaining better social status. As we recall, Esperanza detests her hair because it resembles a broom: "No matter 
how much lye Esperanza combed through her hair, it curled and crimped and fanned out like an old broom" (Cruz 14). Esperanza treats race as tangible and alterable because she views whiteness as perfection, and she is ashamed of her own Hispanic/Dominican race. The attempt of altering race and treating it as alterable through hair is commonly practiced in the Dominican Republic. Kunsa discusses that, 'race is a fluid, transforming, historically specific concept' ...whose meaning at any moment must be grasped in relation to the specific circumstances of that time and place ... The flexible nature of whiteness in the Dominican Republic is reinforced by the fact that hair, 'an alterable sign,' is the primary identifier of race; 'hair that is racially compromising can be mitigated with care and styling' ... and by 'improving' their hair, individuals have the power to change their racial categorization, to become white. (213)

Dominican women undergo these extreme measures because white hair is a sign of wealth and higher social standing. Nonetheless, Esperanza attempts changing Santo to fit the mold she views on television.

The desire to alter her husband's hair exemplifies Esperanza's perception that non-white physical traits and appearance are neither attractive nor a sign of economic wealth: "She wanted him to tuck in his shirts. She patted pomade on her hands and pushed his hair away from his face to mimic Bobby Ewings. / Mujer, what is that stuff you put in my hair? / —I'm trying to fix it" (Cruz 14). As we recall, by the 1960s, U.S. imperialism influenced all the Caribbean islands, and a majority of Dominicans favored white characteristics because it represented prosperity. Therefore, by applying pomade in 
Santo's hair, tucking in his shirt, and more importantly, attempting to make him look like a white American actor, Esperanza attempts erasing reminders of poverty and Dominican ethnicity. She desires Santo to resemble Bobby Ewing, an attractive symbol of American normalcy and prosperity. As Kunsa discusses in her article, “...the white body serves as a 'the somatic norm' against which all bodies are judged: the physical traits (e.g. facial features) if light-skinned races are considered aesthetically pleasing and those of darkskinned races ugly, with blacks deemed the worst because of their distance from the white norm" (219). Additionally, Patrick Duffy represents the epitome of a whiteAmerican-male, a symbol of dominance and of the seductive story of American prosperity. It is now apparent that to other less powerful nations, American identity signifies a white and male dominating force as a site of power. By changing Santo's hair, Esperanza believes she can shift their access to power, decisions, jobs, wealth, food, progress, and economic growth, which she attributes to the color of their skin and the texture of their hair. Nonetheless, these efforts for white characteristics prove insufficient to Esperanza who soon realizes that she can no longer bear living in the Dominican Republic.

Esperanza's hasty migration results from gradual buildup of racial frustration and Dominican history. Her decision to migrate happens literally within one page in the novel; emphasizing the severity of racial and historical frustration she feels:

—No mas! Esperanza yelled at her own reflection in the blotchy mirror that made her brown skin look as if she was riddled with beauty marks. Maldita vida mia, I'm going to Dallas, she had whispered to herself, afraid that if someone heard her, they'd convince her to stay in Los Llanos. 
She'd heard of people who made their way to Nueva York. Dallas couldn't be far off. (Cruz 14)

By literally cursing her life: "Maldita vida mia"/ "Damn life of mine," her verbal outburst represents people living in poverty and marginalized because of skin color in the D.R. Additionally, Cruz emphasizes Esperanza's physical characteristics to illustrate the racial favoritism existent in the Dominican Republic. Esperanza's "brown skin riddled with beauty marks" depicts a woman annoyed with the appearance of her skin. Through the mirror reflection, the American and the Dominican versions of racism intersect in Esperanza's life and become apparent. As previously stated, the impact of Trujillo's white favoritism and the effects it had on Dominicans, like Esperanza, has pre-imposed the idea that white is the desirable and prosperous race. The phrase emphasizes Esperanza's frustration with the reflection she views in the mirror because it does not resemble the prosperous Ewings nor the white and wealthy Dominicans of her home country. Her brown skin and blotchy mirror create a distorted and exaggerated image of her poverty-ridden circumstance.

The American propaganda and the context of the television shows have influenced Esperanza into believing she is inferior. Contrary to Miraluz, who joins the Invisible Ones, whom value their Dominican identity and plan a civil revolution, Esperanza watches television and formulates that white American identity is the answer to prosperity and happiness. The influence from television provides Esperanza with the hope that she seeks for a better future. Her name translates into hope, representing the significance of her belief of an exceptional life as a white-American. It is here that Esperanza differs from the other citizens of Los Llanos. While other Dominicans seek a 
solution for a better social and economic environment, Esperanza ceaselessly dreams and hopes for a fantasy-like reality of American life. For Esperanza, the desire to be white is once again reinforced. On the other hand, the frustration with her skin evokes discontent with her present economic class in Los Llanos. Esperanza's frustration represents an individual not free to choose her class identity. However, once living in the U.S., Esperanza's obsession with material objects further becomes representative of stagnation and misunderstanding of American economy which results in her becoming a bad capitalist.

Upon living in the U.S., Esperanza's obsession with material objects escalates. She endlessly watches episodes of Dallas and uses credit cards to purchase clothes and home goods. She additionally looks through clothing magazines and selects the objects she desires: "Esperanza escaped to her room to watch Dallas reruns even though she had seen most episodes. . . Why couldn’t Esperanza have all the things she wanted? ... Esperanza needed a new look. . Esperanza hid away the store catalogs where she had circled all the things she wanted" (Cruz 31-2). Through Dallas, Esperanza adapts American ideals, yet she does not learn the workings of a capitalistic economy nor understand capitalism and the repercussions of unpaid debt. Soon Esperanza finds herself in debt and has no knowledge about how to pay back the money she owes.

While residing in New York, Esperanza loses control of her shopping habit because she learns capitalism from Dallas. Esperanza holds no prior knowledge about the true workings of an American economic system. She additionally does not understand that the Ewings depict a fictional representation of life in the United States. Nonetheless, Esperanza perceives the wealth presented in Dallas as the norm for all American citizens 
and thus assumes that the show epitomizes and reflects the true components of a good consumer and capitalist. Through Dallas, Esperanza quickly learns to become a superfluous shopper: “Pamela never says, I love this necklace, but because I don't I need it, I won't buy it" (Cruz 32). It is here that we see Esperanza's spending habits are a result of the influence from Dallas. Additionally, Esperanza wants the life portrayed on television and advertisements: “. . . the Gucci bag, just like the one in the magazine ad... she watched Buy $T V$, and salivated over the pearl necklace that regularly cost $\$ 250$, but if she bought it within the next ten minutes, she could have it in three installments of \$29.99" (Cruz 33). Here, the television and magazine advertisements influence her idea of American life. Simply stated, Esperanza learns American capitalistic consumer culture from media. This type of negative influence prevents or halts emigrants like Esperanza from achieving economic independence.

Esperanza represents the many emigrant workers arriving to the United States who are inappropriately educated about the American economy through media. This type of learning behavior through television is representative of continuing the trend of Northamericanization. As previously discussed in the introduction, Northamericanization epitomizes the impact of American goods and culture onto other countries like the Dominican Republic. Upon arriving to the United States, Dominican emigrants turn to television and material goods as tools and guidance for attaining a sense of American identity. Although they desperately attempt to assimilate into the culture by learning from popular television shows, this method proves disadvantageous. Uninformed emigrants like Esperanza learn that they can quickly apply for credit cards and purchase the things they want but do not understand the concept of building good credit, repayment of debt, 
and accruement of interest rates. The misunderstanding about the operations of capitalism have thrown migrant workers, such as Esperanza, into a system of poverty and debt. However, for Esperanza, both the debt and the poor economic advancement are results of her incessant need to try to achieve the economic status of the Ewings. No matter what she buys, she is not Ewing level yet, and therefore needs to buy more. Esperanza cannot be content until she is an Ewing. This is specific to Esperanza's mentality and separate from the more common Dominican/immigrant journey in the United States.

Esperanza's accruement of debt is a result of lack of job opportunity in New York. In the novel, Esperanza desires a dress she sees Pamela Ewing wearing on Dallas: "In the campo, the women would say it's not the dress, it's the hanger that makes the dress, but in America, that wasn't true. To be important, one has to look important" (Cruz 31-2). Here the dress holds significance for Esperanza because she recognizes the importance of the dress, as a 'thing' that determines her social status. In her mind, power resides in the object, not in the individual. By believing that the dress holds the power, Esperanza focuses on the image of success. She does not focus on the realistic process of purchasing the dress, or acquiring the proper skills for pursuing social and economic power. As previously discussed, through media propaganda, Dominicans understood American life to be the answer to their lack of wealth. Thus, before arriving to the U.S., many Dominicans already had a preconceived idea of their American Dream. According to Pessar, “...the visual images of life in the United States that Dominicans on the island receive via cable and advertising remain strong inducements to migrate" (40). On the other hand, the emigrant experience of many new arrivals to the United States consisted of unrealistic understandings of success in America. Since the mid-80s, employment 
opportunities declined greatly in New York City, where many emigrants like Esperanza reside. Similar to the employment situation in the D.R., access to well-paying jobs and economic stability continue to be out of grasp in the U.S. Consequently, Esperanza loses control of her buying habits and creates loss of self-agency through debt because it causes economic restraint.

When Esperanza loses control of her buying habits, debt causes her to become a bad capitalist by creating an opposition to the mythic American Dream; thus, she lessens her chances of self-agency. Additionally, when she cannot access the material wealth she sees on Dallas, Esperanza becomes an excessive American consumer. "The more she bought, the more insatiable she became" (Cruz 33). In other words, Esperanza reproduces herself through the continued purchasing. As previously mentioned, objectification is the process of an individual fixating on the external, material reality. Through the endless purchasing of material goods, Esperanza practices having control of a world she has created instead of a world in which she has no power nor possibility of material wealth. However, Esperanza's objectification also has negative repercussions. In the same fashion that objects enhance Esperanza's agency, they also constrain her. Miller discusses the constraint caused by objects: "Commodities are not inherently good or bad, but you can't have their benefits without entailing the risk that they will oppress you" (63). Therefore, Esperanza creates a form of oppression and a contradiction. Her consumption gets out of control and becomes autonomous in the form of debt. Esperanza originally thought that attaining more things would enhance and liberate her life experience through exercises of self-agency, but debt has created an opposition to the mythic American Dream because she becomes a bad capitalist. By owing so much money, Esperanza draws 
herself further away from becoming wealthy and self-sufficient. As a result, Dallas and things both expand and constrain Esperanza. She enhances her subjective experience by applying previous knowledge acquired in the D.R.; yet, applying historical and cultural context epitomizes, that “... [Esperanza] would not simply rely on some unknowable notion of a pure natural selfhood, but would produce [her]self endlessly as a response to [her] cultural and historical context" (Mansfield 63). In the D.R., Esperanza learns that she does not have the means to produce objects; consequently, when she lives in New York, instead of making objects, Esperanza purchases endlessly. Her autonomous spending results in her becoming an American consumer beyond her financial means and being categorized as a debtor.

Esperanza is categorized as a debtor when the collection agencies call her because she owes thousands of dollars to various credit card companies. A representative from a collection agency calls Esperanza and states: “... we're collecting a debt of yours for two thousand dollars... You can work out a payment plan with us. If not, we'll be forced to go to court" (Cruz 67). When Esperanza is called upon by the collection agencies, she becomes a subject classified as a bankrupt and answerable to the law if she does not pay back what she owes. Esperanza owes money and is categorized by the bank and the collection agencies as bankrupt and a debtor. Additionally, upon being called, Esperanza immediately defines herself as a criminal who wears, "an orange jumpsuit behind a glass wall," if she does not comply (Cruz 67). Here her chances of gaining self-agency are lessoned because she risks going to jail and losing all freedom. The categorization of debtor ceases all chances of being independent and in control of her financial wealth. Esperanza soon realizes that she must become a responsible capitalist and consumer to be 
self-sufficient. However, Esperanza attains freedom by recognizing Dallas working as a system of things and by releasing herself from the categorization of monetary debt.

The scene where Esperanza meets Patrick Duffy while riding on the subway train is a depiction of the mythic American Dream being shattered and a depiction of the powerful effects of media onto an individual's decisions and self-identification. Within the novel, the mythic American Dream takes on the embodiment of Patrick Duffy as, "A tall white man getting on the train, holding his paper" (Cruz 247). But this is no ordinary "tall white man." This is Bobby Ewing from Dallas, the show that has conceptualized and fortified Esperanza's purpose for moving to the U.S. and wanting to attain material wealth. As previously mentioned, Patrick Duffy represents the site of power in the Americas. Thus, Patrick Duffy represents the effects of media, as an integral influence on the decisions she has made. Furthermore, Dallas has worked as a system of things constructing Esperanza's identity. As we recall from Miller, "Things, not, mind you, individual things, but the whole system of things, with their internal order, make us the people we are" (53). Patrick Duffy and Dallas represent vehicles within the system of objects that Esperanza has dutifully adhered to for years to attain the mythic American Dream and create her identity. Esperanza's conversation with Duffy is her discourse with the mythic American Dream. When Esperanza looks at Patrick Duffy, she views the totality of Dallas and all the constructed meanings and events that she has created because of the show: the obsession with material objects, her desire to leave the Dominican Republic, her consumption of debt, and the naming of her children. It is apparent when, “[Esperanza] didn't know where to begin. Should she tell him about la Loca's hence or the yola, or when Dallas was born?" (Cruz 248). Esperanza attempts 
telling Patrick Duffy/Dallas/the mythic American Dream how it/he has worked itself into every aspect of her life and has influenced her to make many decisions: "She went into her purse to look for a photograph of Bobby and Dallas to show him how he was partly responsible for everything that had happened in her life" (Cruz 247, my emphasis). At this point in the novel, it is evident that the power of media and the system of things have been working on Esperanza in subtle ways. So much so, that Esperanza has named her two children after the show in attempts to emulate the characters on Dallas.

The naming of her children additionally represents how objects have internally worked to impact the identification of her offspring. By naming her children after the show, Esperanza attempts determining who her children will become: white-American citizens. Furthermore, Esperanza represents an audience member who is under the power of the television show, Dallas, which affects and seeps into the subject's life in the subtlest form. Nonetheless, Esperanza soon realizes that neither her identity, nor her children's identity, rely on the television show. More importantly, Esperanza recognizes that she no longer identifies nor desires the mythic American Dream through material possessions or white-American sense of self.

In the Patrick Duffy scene, Esperanza's awakening from the mythic American Dream represents the effects of media through Dallas and her new relationship with material culture as tools for self-agency. While speaking to Patrick Duffy, Esperanza suddenly realizes that, “Bobby Ewing wasn't as handsome as [she] imagined. Seeing him changed everything. She wasn't going to Dallas, or California for that matter. Over sixteen years in Nueva York, hoping to live her dream, and suddenly someone turned on the lights and she was awake" (Cruz 253, my emphasis). Esperanza acknowledges that 
she has been envisioning a false reality for herself. The fact that Patrick Duffy is not as handsome in person as in television is the first signal initiating Esperanza into a new realization of reality, one in which she no longer desires attaining the mythic American Dream. The amount of time that has lapsed between Esperanza's departure from the Dominican Republic and how long she has been in New York endlessly accumulating 'things' becomes clear. Esperanza recognizes that she is changed and will not return to being the same person.

Additionally, Dallas no longer holds power over her sense of identification. In the following quote, Esperanza compares reality to the moon, further epitomizing her awakening and recognizing the undetected impact from the television show: "Reality is like the moon. You know it's there, but you don't always see it. And if you do acknowledge it, it can only help and maybe even inspire, thought Esperanza. And she wanted to see the moon and jump over it. Something in her life had to change" (Cruz 255). The moon alludes to the invisible influence of Dallas and material objects which previously controlled and determined Esperanza's desire and drive. Furthermore, the moon reference relates to Miller's definition of the humility of things in which, "[it] implies that when something is sufficiently evident it can reach a point at which we are blinded to its presence, rather than reminded of its presence" (51). Like the moon, which is present in an individual's everyday reality yet remains unnoticed by many, Dallas has also been present in Esperanza's daily experience. Thus, through the moon reference, readers recognize the unseen effects of television. Here the moon alludes to the depth or to the extent of the show's influence on Esperanza's life and choices. However, by stating, "Something has to change", she recognizes her function in society is no longer 
connected with accumulating 'things' and desiring white-American identity. Esperanza's desire no longer stems from Dallas; her societal role is no longer connected with the object materialism she views on the television show. Now armed with self-awareness, Esperanza desires to live in her present reality: "What had she been waiting for? Did she really think a man like Bobby would knock on her door and sweep her off her feet?" (Cruz 253). It is here that Esperanza finally notices the illusory and undetected components of the life she attempted creating since living in Los Llanos.

By recognizing the illusion of the show and the corresponding mythic American Dream that she had hoped to achieve, Esperanza attains new awareness, breaks away from categorization of debtor, and becomes a realistic consumer. Once she discovers the extent of the influence from media and how much it has affected and caused her to attain debt, Esperanza no longer believes in the mythic American Dream. Per Valovirta et al, this loss of belief can be viewed as a form of betrayal: "Esperanza's sense of betrayal from the disappointing meeting comes to encompass her whole life in the United States, as the dream of a better life thanks to Dallas had now been destroyed. The meeting on the subway highlights the failure of Esperanza's American life" (238). Esperanza's meeting with Patrick Duffy now represents a form of self-recognition.

Armed with this new recognition, Esperanza no longer views her role in society as an individual desiring material goods. She decides to settle her credit card debt when she thinks, "If she didn't pay those damn credit cards, she wasn't ever going to own anything but the shoes on her feet... [She tells the bank teller] You have to help me. If I don't' pay these bills, I can't get a loan, I can't buy anything. I work and work. I have no retirement plan. I'm not getting any younger" (Cruz 253). Here Esperanza no longer 
wishes to be categorized as a debtor and seeks assistance from the credit union. The bank representative assists Esperanza: “We'll make a plan. Don’t worry, Ms. Colon, it’s less scary than you think. Maybe we can clear up your debt and get you to start investing" (Cruz 254). By assisting and informing Esperanza, the bank teller provides her with the knowledge and power necessary to take control of her credit. Furthermore, this is no ordinary bank. It is a credit-union, an institution dedicated to assisting and serving people of the community. The fact that Esperanza receives assistance from a credit-union representative ensures that her financial situation will improve, and she will rise above poverty and debt. And so, the role of the bad capitalist or consumer is no longer relevant to Esperanza. Now armed with knowledge and self-awareness, Esperanza views herself as separate from the former idea of the woman that attains 'things' to feel powerful or successful. She decides to return to the D.R. and give away most of her possessions. By giving away most of her material possessions, Esperanza recognizes her own contribution to material culture and reverses her role as a bad consumer to a good capitalist. Additionally, this is when Esperanza reaches a moment of clarity and finally attains self-agency. In the beginning of the novel, Esperanza's obsession with material culture causes her to leave her home country; however, at the end of the novel, Esperanza returns to the Dominican Republic and bestows her family with the material goods she has accumulated. Therefore, failure of the mythic American Dream assists Esperanza in a positive and beneficial way. As she spreads out the products she has brought with her, she feels a sense of contribution: "Maybe she hadn't accomplished what she'd set out to do just yet, but when she looked at the things she had bought for her family, the history was there in the clothes, she saw her labor. Every piece of clothing she had earned from 
her own sweat. Every hour of sweat was inside each garment" (Cruz 277). Until this moment, Esperanza has not viewed her interaction with material culture from the perspective of a provider of material goods. However, Esperanza has now reversed her role because the giving away of things places her in the position of the responsible contributor to material culture rather than a reckless consumer. More importantly, Esperanza recognizes the fruit of her labor and she has now gained self-agency. Esperanza acknowledges her own labor and assigns value to the clothing she bought with the money she earned with that labor. She waits a long time to return to the D.R. because she wanted to come back with proof of success; however, Esperanza's proof is in the labor she put into attaining the clothes she will give away. This labor is more than mere work to attain material commodities, it is the material manifestation of her journey of becoming a good capitalist through the mythic American Dream. Dallas is finally not a factor in how Esperanza values or appreciates something. She additionally is no longer taking or seeking to gain material objects. Esperanza acknowledges for the first time that she now has more to provide for herself and her family and thus becomes independent. The things that she so desperately sought to acquire in the beginning of the novel are no longer important for her to have a sense of economic stability, power, or purpose. Furthermore, the fact that she is in the Dominican Republic emphasizes her renewed awareness of reality for herself and her family. By bestowing her family with the 'things' she so desperately desired and sought to possess, her return to the D.R. brings Esperanza's exchange with material objects to a full circle. She left her home country with the intent of gaining material wealth and she returns with an abundance of things to give away. Esperanza is now more present in her actual reality. She is finally aware of 
what the true value of what she owns outside of the Ewing connection. By giving away most of the objects she purchased on credit, Esperanza recognizes that she was not missing any 'thing' at all and that she will attain happiness without 'things'. Esperanza no longer needs "more." She can finally stop and acknowledge that she has status, that she has independently progressed through exercising self-agency, and done something good. 


\section{CONCLUSION}

This thesis has focused on material culture within the Dominican Republic and the effects of material culture on Dominican migrants within the United States. Let it Rain Coffee depicts how people living in the Dominican Republic become affected by American ideology through media propaganda and government censorship emphasizing favoritism toward white-American cultural values and lifestyle. Many Dominicans desired and sought to emulate the life projected on television screens, a life of wealth, comfort, and political and economic stability. Esperanza represents a character heavily affected by and attempting to emulate the mythic American Dream. She desires the material wealth she views on Dallas; yet emulation is not feasible due to lack of material culture in the Dominican Republic, and she migrates to the United States. While in the D.R., Esperanza is affected by historical events that influence her understanding of selfidentity and the type of life she wants for herself. The impact of American media as an idealistic cultural influence on less powerful nations must be further analyzed.

However, the mythic American Dream applies to the idea of instantaneous wealth and it correlates with Esperanza's story of coming to America; equating to the delusion of the immigrant experience. In the novel, Esperanza's reality is reinforced with every Ewing-like object but her story comes with a warning because she accrues debt, loses sense of reality, and self-agency. Her immigrant story sets her apart from others because Esperanza arrives to the United States already wanting Ewing-class level of wealth. Per Esperanza it is not satisfactory to just reach a middle-class wealth; her desire for wealth represents the majority of people who seek unrealistic methods for becoming rich. Yet Esperanza acts upon that desire actively. Many people dream of magically becoming rich, 
but they don't begin to work on it as Esperanza does. The altered versions of reality portrayed through media also represent a current trend in the idea that everyone can attain immense wealth. Instead of focusing on realistic ways to attain economic stability such as investing in a home or use one's earning potential, many people seek alternate methods or an effortless solution to becoming rich.

Additionally, individuality is becoming more and more dependent upon media for answers about self-identification and happiness success. Therefore, this thesis begs the question: What power will media and material culture have over our future identities? Miller explains that, “Objects don't shout at you like teachers ... but they help you gently learn how to act appropriately" (Miller 53). Similarly, the identity of many individuals intrinsically, and in many cases, unnoticeably, depends on the fictional images of happiness and the lavish objects they see on television and other forms of media. The message constantly depicted through media outlets is: It's not about who you are but what you have. If identity is truly formulated based upon our interaction with material objects, then what types of material objects will people begin to turn to for selfidentification or sense of progress and happiness? On the other hand, the fact that Esperanza incessantly cares more and relates more to the characters on a television show, symbolizes the virtual relationships many individuals have come to prefer instead of their present realities. If social media and the Internet are becoming alternative outlets for creating a sense of virtual identity or reality, what will motivate people to establish true connections with their family and friends that are real and right beside them? 


\section{REFERENCES}

Ang, Ien and Judy Millen. "Watching Dallas: Soap Opera And The Melodramatic Imagination" // Review. Resources for feminist research, vol. 16, no. 2, 1987, pp. 46-47.

Appadurai, Arjun. The Social Life of Things: Commodities in Cultural Perspective. Cambridge Cambridgeshire: Cambridge University Press, 1986. Print.

Atkins, G P, and Larman C. Wilson. The Dominican Republic and the United States: From Imperialism to Transnationalism. Athens: University of Georgia Press, 1998. Print.

Boyce-Davies, Carole. Black Women, Writing and Identity: Migrations of the Subject. New York: Routledge, 1994. Print.

Chandler, Daniel. Semiotics: The Basics. $2^{\text {nd }}$ ed. New York: Routledge, 2002. Print.

Cruz, Angie. Let it Rain Coffee. New York: Simon \& Schuster, 2005. Print.

---. Soledad. New York: Simon \& Schuster, 2001. Print.

Eagleton, Terry. Marxism and Literary Criticism. Berkeley: University of California Press, 1976. Print.

Valovirta, Elina, et al. "The Smell of an Impossible Dream: Dallas, Migration, and Creative Failure in Angie Cruz's Let It Rain Coffee". The Journal of Commonwealth Literature, vol. 49, no. 2, 2014, pp. 229-242.

Hall, Stuart. "Living with Difference: Stuart Hall in Conversation with Bill Schwarz." Soundings 37 (2007): 148+. Academic OneFile. Web. 12 Mar. 2015.

Harvey, Karen, ed. History and Material Culture. New York: Routledge, 2009. Print.

Kaussen, Valerie. 'Slaves, 'Viejos', and the 'Internationale': Modernity and Global Contact in Jacques Roumain's 'Gouverneurs de la rosée." Research in African Literatures, vol. 35, no. 4, 2004, pp. 121-141.

Kunsa, Ashley. "History, Hair, and Reimagining Racial Categories in JunotDíaz's The Brief Wondrous Life of Oscar Wao.” Critique: Studies in Contemporary Fiction, vol 54,no. 2, 2013, pp. 211-24.

Latorre, Sobeira. "Shifting Borders: An Interview with Angie Cruz." Latino Studies 5 (2007): 478-488. Web. 15 Feb. 2015. 
Mansfield, Nick. Subjectivity: Theories of the Self from Freud to Haraway. St Leonards: Allen \& Unwin, 2000. Print.

Miller, Daniel. Stuff. Malden: Polity Press, 2010. Print.

Moreno, Marisel. "Dominican Dreams: Diasporic Identity in Angie Cruz's Let it Rain Coffee.” Sargasso 2 (2008-9): 101-116. Web. 26 Nov. 2014.

Pessar, Patricia R. A Visa for a Dream: Dominicans in the United States. Boston, Mass: Allyn and Bacon, 1995. Print.

Shalabi, Rasha Al. "Shared History of the United States and the Dominican Republic in Angie Cruz's Let it Rain Coffee." Label Me Latina/o, vol. 5, 2015, pp 1-18. 